\title{
部分不活化花粉による二倍性種なしスイカ生産のための蕾受粉
}

\author{
杉山慶太*・阿久津雅子 a \\ 独立行政法人農業・食品産業技術総合研究機構北海道農業研究センター 062-8555 札幌市豊平区羊ヶ丘
}

\section{Bud Pollination for Production of Diploid Seedless Watermelon Using Partially Inactivated Pollen}

\author{
Keita Sugiyama and Masako Akutsu
}

National Agricultural Research Center for Hokkaido Region, Hitsujigaoka, Toyohira-ku, Sapporo, Hokkaido 062-8555

\begin{abstract}
Diploid seedless watermelons are presently produced by pollination with partially inactivated (soft X-ray irradiated) pollen. Bud pollination on the day preceding flowering was tested as a means of reducing labor in seedless watermelon production. The fruit set rates by pollination in the afternoon, as well as those on the day of flowering, were higher than those in the morning. There was no difference in fruit weight, fruit shape, rind thickness, soluble solids (Brix), flesh color, rind hardness, and number of empty seeds between the fruits resulting from bud pollinations and the fruits produced by pollination on the flowering date. These results were almost similar to those of partially inactivated pollen preserved for about one year. Our previously established seedless watermelon production method involved making the soft X-ray irradiated pollen, covering the female flower with a bag before flowering, artificial pollination, and covering the female flower after pollination. With bud pollination, the work involved in covering the female flower before flowering could be omitted, and since preserved inactivated pollen could be used, the total working hours were reduced by about $63.5 \%$.
\end{abstract}

Key Words : empty seed, laborsaving, parthenocarpy, soft X-ray irradiated pollen, stored pollen キーワード：保存花粉, 軟 X 線照射花粉, しいな, 省力化, 単為結果

\section{緒言}

種なしスイカは三倍体を利用したものがほとんどであ り，二倍体スイカの花粉を三倍体スイカの雌花に受粉する ことによって果実が生産される（Kihara, 1951）。その後, Sugiyama・Morishita（2000）は，二倍体のスイカに軟 X 線 を用いて照射された花粉（以後，部分不活化花粉）を受粉 することによって単為結果し, 種なし果実が得られる現象 を見いだした。この部分不活化花粉を利用した種なしスイ カの作出方法は，一般的に栽培されている二倍体のスイカ 品種を用いるため，産地で栽培されている品種を利用でき る利点がある。しかし，部分不活化花粉を利用した種なし スイカの生産では, 一般的なスイカ生産に比べて部分不活 化花粉の作出や他家受粉の防止作業などが加わり, より多 くの時間を要している.

これまで部分不活化花粉を利用した種なしスイカの生産 のためには, 生産者が開花前の雌花に袋掛けを行い（他家受

2009 年 4 月 30 日 受付. 2009 年 11 月 20 日 受理.

本研究は生研センター異分野融合研究事業において行われ，一 部は北海道園芸研究談話会で発表した.

* Corresponding author. E-mail: keita@affrc.go.jp

a 現在 : 独立行政法人国際農林水産業研究センター
粉の防止), 開花雄花を早朝に収集し, 軟 X 線を照射して花 粉を部分不活化させた後に受粉を行い, 再度袋掛けの作業を 行ら必要があったまた，雌花の結実能力から午前中に受粉 作業を終えることが望ましいため, 時間的な制約も大きいな ぞ, 開花当日に受粉できる数は限られており, 種なしスイカ の量産化が困難であった. そのため, 現行の生産過程を改善 して量産化するためには, 他家受粉の防止作業の省力化およ び部分不活化花粉の作出の分業化が必要である. 部分不活化 花粉の作出については, スイカ花粉の長期保存技術が開発さ れたことにより（Akutsu・Sugiyama, 2008），専門業者による 生産者への部分不活化花粉の提供が可能となり, 生産者が受 粉の作業に専念できる体制ができた.

残された解決すべき課題として，他家受粉の防止作業の 省力化がある．訪花昆虫によって部分不活化していない花 粉が受粉されると，種子が形成されるため，雌花の開花前 と受粉後の他家受粉の防止作業は必須である. 他家受粉は ミッバチ，コハナバチ，ハナアブおよびアリなどの訪花昆 虫により行われ，農薬の散布や寒冷紗・防虫ネットなどで 歹他家受粉の防止効果は認められるが，効果を高めるため には雌花の開花前と開花当日の受粉後の袋掛けなどの作業 が必要となっている，スイカにおいて蕾受粉による果実の 作出が可能となれば，開花前の袋掛けなどの作業が不要と 
なり，大きな省力化となる，ウリ類の蕾受粉については， キュウリやメロンでの報告があり（熊沢・南川，1937; 鈴 木, 1979; 八柳, 1936), 開花前日には結実能力が備わって いることが知られている。 しかし，スイカでは開花当日の 受粉と結実率との関係についての報告はあるが (下内, 1932; 杉山，2001）, 開花前の受粉と結実率との関係についての調 查は汪とんど行われていない，そこで, 他家受粉の防止作業 の省力化を目的として, 開花前日の受粉による結実率と果実 品質について調査を行った. また, 保存した部分不活化花粉 を利用し，開花前日に受粉を行ら場合の作業時間について， 現行の生産方式の作業時間との比較も行った.

\section{材料および方法 \\ 1. 受粉時刻と着果率の関係 \\ 1）開花雄花の当日の花粉を用いた受粉}

2006 年 6 月 15 日に直径 $12 \mathrm{~cm}$ のポットに “富士光 TR' を播種し，7 月 10 日に幅 $300 \mathrm{~cm}$ の 1 畧に株間 $60 \mathrm{~cm}$ で 50 株定植し, 露地で栽培した. 整枝方法として主枝を摘心後, 側枝 3 本整枝とした．施肥は， $1 \mathrm{a}$ 当たり成分量で窒素，リ ン酸, カリウムを各 $1.2 \mathrm{~kg}$ 施用した。 実験区として部分不 活化花粉を雌花の開花前日の 9，12，14 および 17 時に受粉 する区，対照区として開花当日の 9 時に受粉する区を設定 した。 また，部分不活化していない無処理の花粉を開花当 日の 9 時に受粉する区も設けた. 1 側枝につき 1 雌花の受 粉を基本として, 1 処理区 10 側枝以上の受粉となるように ランダムに受粉し，7 日後に結実率を調査した。結実率は 受粉数に対する結実数で示した. 受粉は 2006 年 7 月 25 日 $\sim 8$ 月 15 日に行った. 部分不活化花粉は開花当日の雄花に 軟 X 線を $600 \mathrm{~Gy}\left(15 \mathrm{~Gy} \cdot \mathrm{min}^{-1}\right)$ 照射して (OM-B205，オー ミック）作出した．9時以降の受粉では照射処理直後にシ リカゲルを入れたシャーレに雄花を封入して $4^{\circ} \mathrm{C}$ の冷蔵庫 で保存して利用した，開花前日の受粉においては，受粉後 に雌花に袋（縦 $12 \mathrm{~cm} \times$ 横 $6.7 \mathrm{~cm}$ ）を掛けて他家受粉を防 止した。開花当日の受粉では, 開花前日と受粉後に袋を掛 けた。な打，開花する前日の雌花は，蕾の花弁が膨ら久黄 色となることで判断した。

\section{2）長期保存花粉を用いた受粉}

2008 年 4 月 3 日にワグネルポット $\left(1 ・ 2000 \mathrm{a}^{-1}\right)$ に園芸 用培土を入れて, 雄花が多く花粉量の多い品種 “Green Seeded’を 1 ポット当たり 3 粒播種した. 整枝方法として 主枝を摘心して側枝を 2 本伸ばし，立体栽培とした．実験 区として部分不活化花粉を雌花の開花前日の 9，12，15 打 よび 18 時に受粉する区, 対照区として開花当日の 9 時に受 粉する区を設定した． 1 側枝につき 1 雌花の受粉を基本と して，7 日後に結実率を調査した. 1 処理区 3 株（1 ポット） とし，4 反復行った。受粉は 2008 年 6 月 13 日〜 7 月 8 日 に行った. 部分不活化花粉は 2007 年 7 月に開花雄花の葯か ら花粉を分離してパラフィン紙に包み，軟 $\mathrm{X}$ 線を $600 \mathrm{~Gy}$ $\left(15 \mathrm{~Gy} \cdot \mathrm{min}^{-1}\right)$ 照射した. 部分不活化された花粉を真空専
用袋に入れて，真空包装機（V-308G，東静電気）により脱 気後に窒素ガスを封入して, $-25^{\circ} \mathrm{C}$ で保存した．開花前日 の受粉では受粉後に袋掛けを行い，開花当日の受粉では開 花前日と受粉後に袋を掛けた. 栽培はガラス温室内で行い, $25^{\circ} \mathrm{C}$ 以上で天空を開けるように調節した。

\section{2. 開花の前日受粉による種なしスイカの品質}

\section{1）開花雄花の当日の花粉を用いた開花前日の受粉}

2006 年に 1.1）と同じ栽培法により，実験区として部分 不活化花粉を雌花の開花前日の 14,16 抢よび 18 時に受粉 する区，対照区として開花当日の 9 時に受粉する区を設定 した. 1 処理区 8 株をランダムに配置し， 1 株当たり 1 果実 の久残して摘果し,受粉後 45 日目に各区から結実した 4 〜 7 果を收穫した。調查項目は，果重，果形，果皮の厚さ，果 肉色，果肉硬度，Brix 抢よびしいなの程度とした。果形は 果実の縦径と横径の割合に基づいて表した，果皮の厚さは 果実赤道部の表皮から赤い果肉部に至るまでの長さを測定 した．果肉色は色彩色差計を用いて果実縦断面の中央部の a*值を測定した。果肉硬度は果実硬度計（KM-1，藤原製 作所）を用いて果実縦断面の 3 か所を測定した．Brixは果

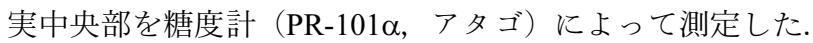
しいなの程度は果実縦断面の両面に含まれるしいなの数に 基づいて評価した

\section{2）長期保存花粉を用いた開花前日の受粉}

2007 年 6 月 6 日に“富士光 TR’を播種し，6月 29 日に ビニルハウス内の長さ $22 \mathrm{~m}$, 幅 $3 \mathrm{~m}$ の 2 竝に株間 $50 \mathrm{~cm}$ で 定植した．整枝方法として主枝を摘心後，側枝 3 本整枝と した．施肥は， $1 \mathrm{a}$ 当たり成分量で窒素，リン酸，カリウム を各 $1.2 \mathrm{~kg}$ 施用した. 実験区として，2006 年に窒素封入後 $-25^{\circ} \mathrm{C}$ で約 1 年間保存した ‘Green Seeded’ の部分不活化花 粉（600 Gy で照射）を雌花の開花前日の $14 ， 16$ および 18 時に受粉する区，対照区として開花当日 9 時に同保存花粉 を受粉する区を設定した． 1 処理区当たり 4 株の 2 反復と した. 1 株当たり 1 果実の久残して摘果し, 受粉後 45 日目 に收穫した。受粉は 7 月 $18 \sim 24$ 日に行い, 調査項目は 2 . 1）と同じとした.

\section{3. 保存した部分不活化花粉の利用と開花前日の受粉によ る省力性}

2007 年 6 月 22 日に“富士光 TR’ を播種し， 7 月 18 日 に長さ $60 \mathrm{~m}$ ，幅 $3 \mathrm{~m}$ の 3 畧に株間 $60 \mathrm{~cm}$ として 100 株定 植し, 露地栽培した. 1 株 3 本整枝とし，8月 $8 \sim 22$ 日に 現行の種なしスイカの生産方式による作業と新たな種な しスイカの生産方式（第 1 図）による作業の時間を測定し た。作業は 5 人の被験者により行われ $(50$ 代・ 1 人， 40 代・ 2 人， 30 代・ 1 人拈よび 20 代・ 1 人)，そ机帒れ異な る日に実施した．また，現行の生産方式による作業時間の 測定と新たな生産方式による作業時間の測定についても 異なる日に実施した。な拈，軟 X 線の照射時間は40 分 (600 Gy) とした. 


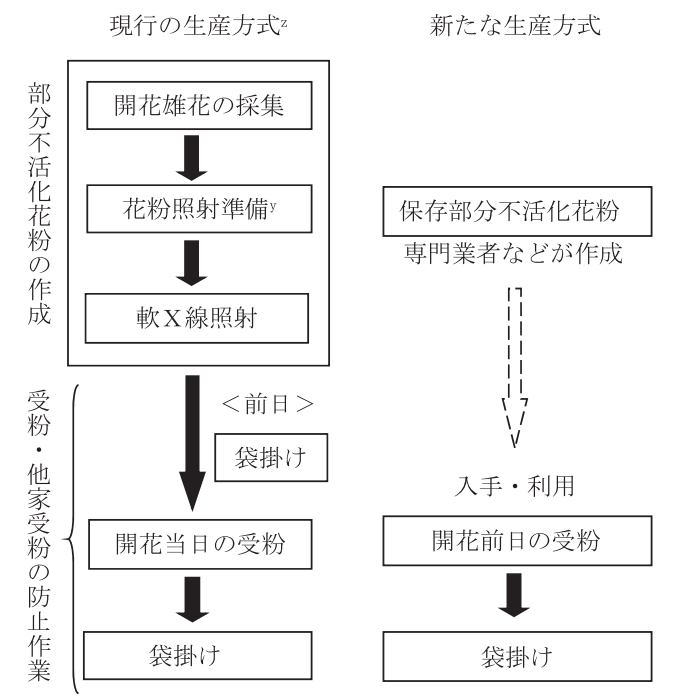

第 1 図 部分不活化花粉による種なしスイカの生産方式の比較 z生産者がすべての作業工程を行う

$\mathrm{y}$ 雄花の花弁除去と照射網への設置

\section{結果および考察}

\section{1. 受粉時刻と着果率の関係}

\section{1）開花雄花の当日の花粉を用いた受粉}

開花前日の 9 および 12 時の受粉ではそれぞれ $18.2 \%$, 21.4\%の結実が認められたが, 開花当日の 9 時に部分不活 化花粉を受粉した結実率 $70.0 \%$ の $2.5 〜 3$ 割程度であった (第 2 図). 14 時以降の結実率は急激に上昇し，14 お5び 17 時の受粉では結実率がそれぞれ 75.0\%，71.4\%となり， 開花当日に受粉した結実率と同程度となった。

\section{2）長期保存花粉を用いた受粉}

約 1 年間保存した部分不活化花粉を用いた場合に，開花 前日の 9 時にお抢る受粉では, $18.8 \%$ の結実が認められた が，開花当日の 3 割程度であった (第 3 図). 午後の受粉で は結実率が上昇し，12 時では開花当日の 5 割程度, 15 時以 降の受粉では開花当日の結実率とほぼ同程度となった。

杉山（2001）は雌花の開花当日の結実能力についての調 査から, 結実率は開花当日の午後から急激に低下し, 16 時 頃の受粉では結実が極めて低いことを示した。 スイカの開 花当日での結実能力は詳しく調査されていたが，開花前の 蕾受粉による結実についてはほとんど知られていなかっ た．本実験の結果から，開花前日の午前中には結実能力の あることが明らかとなり，部分不活化花粉を受粉した場合 でも結実することが示された。 また，実験年は異なるが， 約 1 年間保存した花粉を用いた受粉に执いても開花雄花の 当日の花粉を用いた受粉と同程度の結実率が認められ, 保 存による影響はみられなかった. 雄花の多い品種 “Green Seeded’ の保存花粉に执いて子結実が認められたことから， 実用的な利用の可能性も示された。

2006 および 2008 年の実験とも開花前日の午前中では結 実能力が低いため, 開花当日の受粉と同程度の結実率を得

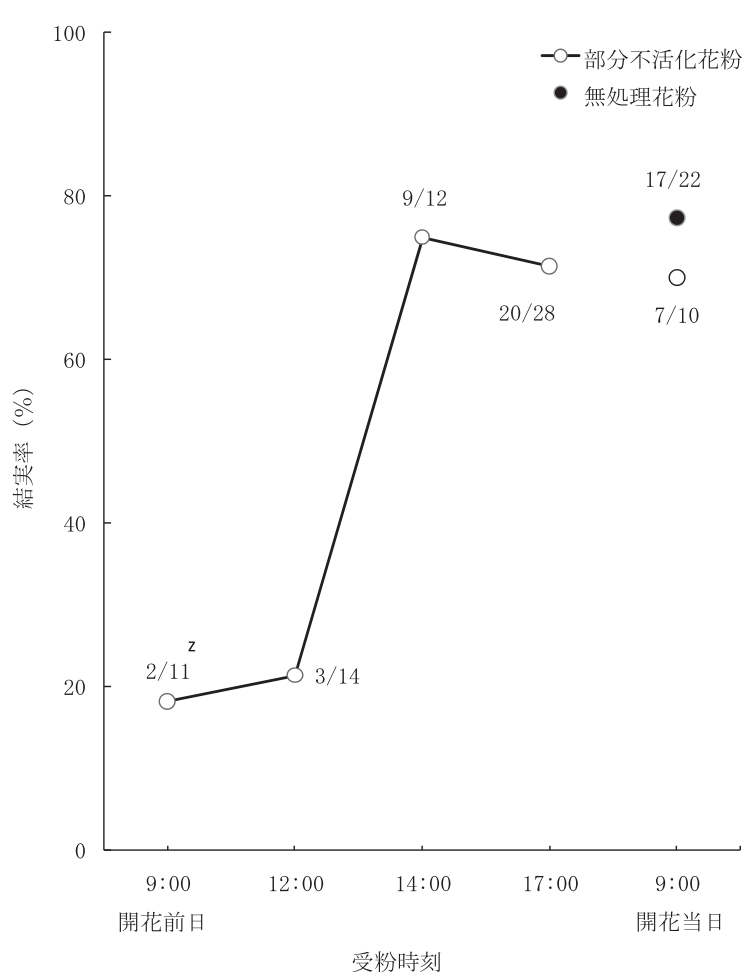

第 2 図 部分不活化花粉の受粉時刻と結実率との関係 (2006 年) z 結実数 $/$ 受粉数

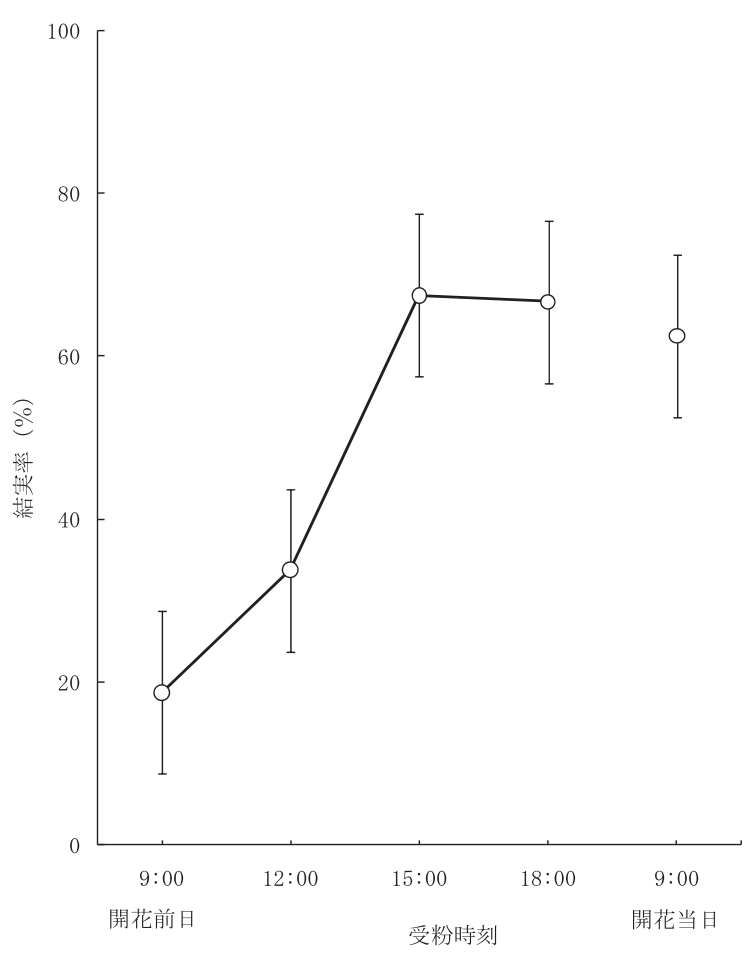

第 3 図 長期保存した部分不活化花粉の受粉時刻と結実率との 関係（2008 年）

図中の縱棒は標準誤差を示す $(n=4)$ 
るためには, 14 時以降の受粉が望ましいと考兄られる. 2006 年の露地栽培および 2008 年のガラス温室内での栽培 では，それぞれ 7 月下旬〜 8 月上旬， 6 月中旬 7 月上旬 と気温の高い時期の受粉であり, 雌花の発育や花粉管伸長 に良好な条件であったと考光られる。花粉発芽率や花粉管 の伸長は温度によって影響され（倉田，1971; 末永，1990； 杉山，2001）, 雌花の発育も気温に影響されることから（倉 田，1972），促成栽培や早熟栽培などの受粉期が低温に遭遇 しやすい作型での開花前日の受粉については, 詳細な結実 調査が必要と考兄られる.

\section{2. 開花の前日受粉による種なしスイカの品質 \\ 1）開花雄花の当日の花粉を用いた開花前日の受粉}

開花雄花の当日の部分不活化花粉を用いて開花前日の午 後に受粉を行った果実は, いずれの受粉時刻でも果重, 果 形，果皮の厚さ，Brix，果肉色，果肉硬度抢よびしいなの 程度とも開花当日に受粉した果実とほぼ同程度の品質の種 なしの果実が得られた（第 1 表）。

\section{2）長期保存花粉を用いた開花前日の受粉}

約 1 年間保存した部分不活化花粉を用いて開花前日の午 後に受粉を行った果実は，いずれの受粉時刻でも対照区と 同程度の果重であった（第 2 表）。また，果形，果皮の厚さ，
Brix，果肉色，果肉硬度扣よびしいなの程度とも受粉時刻 にかかわらず，当日受粉とほぼ同程度の品質の種なしの果 実が得られた。

これまで保存花粉を用いた受粉の果実品質への影響につ いては, Akutsu・Sugiyama (2008) や Sugiyama ら (2002) が，長期間保存された部分活化花粉によって作出された果 実の品質が対照区（開花雄花の当日の部分不活化花粉ある いは $1 〜 2$ 日間保存した部分不活化花粉）の果実とほぼ同 程度であったことを報告している。このことから，花粉の 発芽力（発芽率，花粉管伸長）が低いなどの問題がなけれ ば，保存花粉を用いた開花前日の受粉においても開花当日 の受粉と同等の品質の果実が生産できると考えられる.

以上の結果から，開花前日に部分不活化花粉を受粉する ことにより，開花当日の受粉と同等の種なし果実が得られ ることが示された. 今後, 開花前日に受粉を行らことで, 開花前の雌花への袋掛けなどの作業の省力化が期待され る.また，受粉 3 時間以降の降雨であれば結実に大きな影 響を与兄ないことから（門田・野崎，1965），前日受粉は開 花当日に降雨が予測される場合に，結実向上の技術として も役立つことが推察される.

第 1 表 部分不活化花粉を用いて開花前日の受粉により作出されたスイカ果実の品質（2006 年）

\begin{tabular}{|c|c|c|c|c|c|c|c|c|}
\hline $\begin{array}{c}\text { 処理区 } \\
\text { (受粉時刻) }\end{array}$ & 調査果数 & $\begin{array}{l}\text { 果重 } \\
(\mathrm{kg})\end{array}$ & $\begin{array}{c}\text { 果形 } \\
\text { (縦横比) }\end{array}$ & $\begin{array}{c}\text { 果皮の厚さ } \\
(\mathrm{mm})\end{array}$ & $\begin{array}{l}\text { 糖度 } \\
\text { (Brix) }\end{array}$ & $\begin{array}{l}\text { 果肉色 }^{\mathrm{z}} \\
\left(\mathrm{a}^{*} \text { 值 }\right)\end{array}$ & $\begin{array}{c}\text { 果肉硬度 } \mathrm{y}_{(\mathrm{N})}\end{array}$ & $\begin{array}{l}\text { しいな } \\
\text { の程度 }{ }^{\mathrm{x}}\end{array}$ \\
\hline 開花前日 14 時 & 7 & 5.5 & 1.03 & 14.0 & 13.0 & 22.3 & 0.32 & 4.1 \\
\hline 開花前日 16 時 & 7 & 6.2 & 1.02 & 14.3 & 12.6 & 19.7 & 0.31 & 3.9 \\
\hline 開花前日 18 時 & 6 & 6.0 & 1.06 & 13.3 & 12.8 & 21.1 & 0.33 & 4.5 \\
\hline 開花当日 9 時 & 4 & 6.0 & 1.05 & 12.4 & 12.6 & 27.0 & 0.31 & 4.3 \\
\hline 有意性 w & & NS & NS & NS & NS & NS & NS & NS \\
\hline
\end{tabular}

色彩色差計による $\mathrm{a}^{*}$ 值

y 硬度計（円錐形のプランジャー）による果肉部 3 か所の貫入抵抗值の平均值

x 果実縱断面の両面の評価 : 1 (不良; 縦径 $6 \mathrm{~mm}$ 以上のしいなを 8 個以上含む)，2（やや不良；縦径 $6 \mathrm{~mm}$ 以上のしいなを 6 〜 7 個含む)，3（中；縦径 $6 \mathrm{~mm}$ 以上のしいなを 4 5 個含む)，4（やや良；縦径 $6 \mathrm{~mm}$ 以上のしいなを $1 \sim 3$ 個含む），5（良； 縦径 $6 \mathrm{~mm}$ 以上のしいな無し)

w分散分析により NS は 5\%水準で有意差なし

第 2 表＼cjkstart長期保存の部分不活化花粉を用いて開花前日の受粉により作出されたスイカ果実の品質（2007 年）

\begin{tabular}{l}
$\begin{array}{c}\text { c 処理区 } \\
\text { (受粉時刻) }\end{array}$ \\
\hline 開花查果数
\end{tabular}


第 3 表 保存部分不活化花粉を用いた開花前日の受粉による新たな種なしスイカ生産方式の省力性（2007 年）

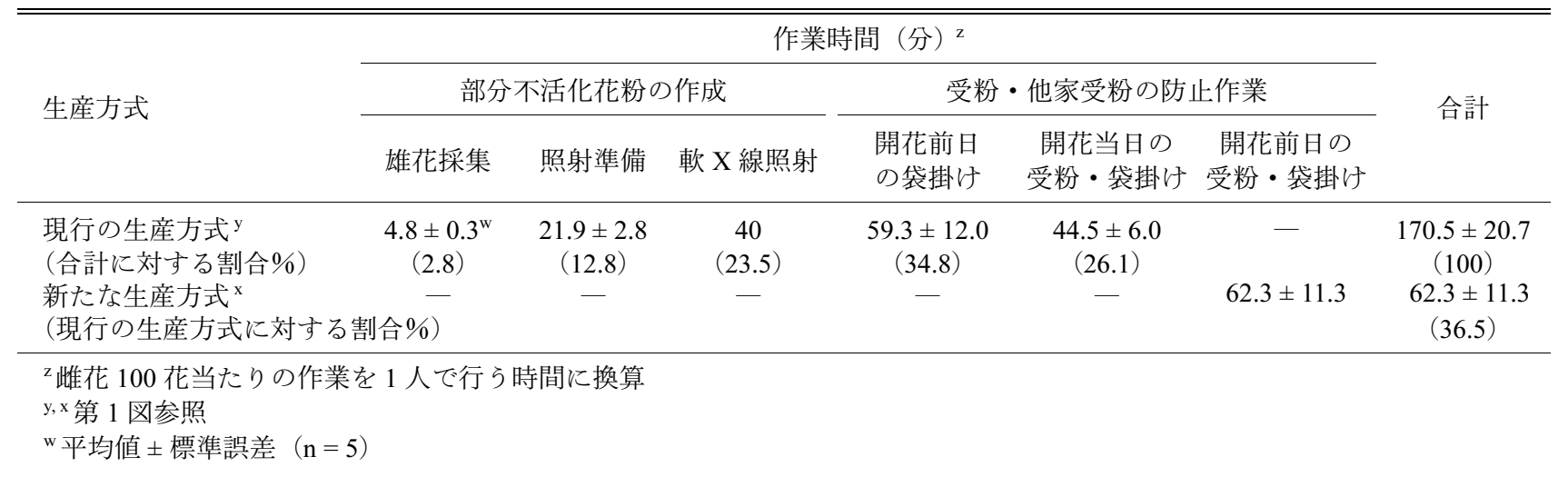

\section{3. 保存した部分不活化花粉の利用と開花前日の受粉によ る省力性}

作業時間には被験者の個人差が大きかったが，保存した 部分不活化花粉を用いて開花前日の受粉と受粉後の袋掛け を行ら新たな生産方式は, 現行の種なしスイカの生産方式 の作業時間と比較して, 全体の作業時間が約 $36.5 \%$ に短縮 （約 63.5\%削減）されることが示された（第 3 表）.

保存した部分不活化花粉を利用することで, 受粉当日の 雄花の採集（約 4.8 分）, 照射準備（約 21.9 分）扣よび軟 X 線の照射 (40 分) の時間が不要となる. この作業は全体の 約 39.1\%（約 66.7 分）を占めることから, 部分不活化花粉 を作出する作業と受粉作業を分けることは大きな労力の削 減になると考兄られる. 現在, 保存した部分不活化花粉は 専門業者などから入手できるようになったことから, 生産 者が部分不活化花粉を作出する必要はなくなり, 受粉作業 のみに専念できるようになった。

現行の受粉・他家受粉防止の作業（開花前日の袋掛け, 開 花当日の受粉 - 袋掛け）に打いて, 開花当日の訪花昆虫に よる受粉を防ぐための開花前日の袋掛けは, 全体の約 34.8 $\%$ (約 59.3 分) の労力を要している. この受粉前の袋掛け 作業は, 前述したように開花前日の蕾受粉によって不要と なる. しかし, 開花前日の受粉・袋掛けの時間（約 62.3 分） が，開花当日の受粉・袋掛けの時間（約 44.5 分）と比較す ると長時間であったことは, 開花前日の雌花を探す時間と 受粉のために蕾の花弁を開く時間を要したためと考えられ る. 開花前日の受粉後の袋掛けも不要になるとさらに省力 化されるが, 開花前日の受粉後に, 翌朝であっても部分不 活化していない花粉が付着すると稔実種子ができることが 観察されており（杉山ら，2007），袋掛けなどの訪花昆虫の 防除は必須と考光られる. 袋掛け作業の効率化に向けては, 接ぎ木用クリップの利用などの取り組みも試みられている が，より簡便に訪花昆虫を防ぐ器具の開発が望まれる.

\section{摘 要}

スイカの部分不活化花粉を用いた開花前日の午前中の受 粉に扔いては結実率が低かったが, 午後からの結実率は急
激に上昇し，開花当日の受粉と同程度となった。開花前日 の午後に部分不活化花粉を受粉して作出した種なし果実 は, いずれの受粉時刻でも開花当日に受粉した種なし果実 と同程度の果重であり, 果形, 果皮の厚さ, 果肉色, Brix, 果肉硬度拈よびしいなの程度とも対照区と注涪同程度の品 質の種なしの果実が得られた。これらの結果は, 約 1 年間 保存した部分不活化花粉を用いた場合も同じあった．現行 の種なしスイカの生産方式（部分不活化花粉の作出，開花 前日の袋掛け，開花当日の受粉，受粉後の袋掛け）に打け る開花前日の袋掛け作業は, 開花前日の蕾受粉によって不 要となった。また，保存した部分不活化花粉を専門業者な ぞから入手して開花前日の受粉を行う新たな生産方式は, 現行の種なしスイカの生産方式と比較して作業時間が約 63.5\%削減されることが示された.

\section{引用文献}

Akutsu, M. and K. Sugiyama. 2008. Establishment of a longterm storage method for soft X-ray irradiated pollen. Euphytica 164: 303-308.

門田寅太郎・野崎 了. 1965. 降雨とスイカの受精障害と の関係. 農及園. 40: 1123-1124.

Kihara, H. 1951. Triploid watermelon. Proc. Am. Soc. Hort. Sci. 58: $217-230$.

熊沢三郎・南川勝次. 1937. 茄・蕃茄・南瓜の蕾授粉と自 然交雑. 園芸の研究. 33: 118-130.

倉田久男. 1971. 花粉の力. p. 28-31. スイカ栽培新書. 養 賢堂. 東京.

倉田久男. 1972. スイカの早出し栽培の問題点. 農及園. 47: 599-604.

下内 稔. 1932. スイカの結実に関する研究. 園芸の研究. 29: 92-104.

末永善久. 1990. 早出しスイカの栽培技術と熊本県での産 地の課題. 施設園芸. 32: 36-38.

杉山慶太. 2001. スイカの多雌花性扮よび耐裂果性の育種 に関する研究. 野菜茶試研報. 16: 265-310.

杉山慶太・阿久津雅子・室 崇人. 2007. 不活化花粉利用 
による種なしスイカ作出のための昆虫防御技術. 北園 談. 40: 84-85.

Sugiyama, K. and M. Morishita. 2000. Production of seedless watermelon using soft X-ray irradiated pollen. Sci. Hortic. 84: 255-264.

Sugiyama, M., Y. Sakata, E. Kitadani, M. Morishita and K.
Sugiyama. 2002. Pollen storage for production of seedless watermelon (Citrullus lanatus) using soft-X-irradiated pollen. Acta. Hortic. 588: 269-271.

鈴木英治郎. 1979. IV 受粉と受精. p. 基 68-71. 農業技術 大系. 野菜編4. メロン類・ スイカ. 農文協. 東京. 八柳三郎. 1936. 胡瓜の花の老幼と結実力. 農及園. 11: 140. 